\title{
Information media literacy to improve working concept comprehension of ignition system with contact breaker through problem based learning
}

\author{
Muhammad Nurtanto ${ }^{1}$, Moh Fawaid ${ }^{2}$, Soffan Nurhaji ${ }^{3}$, Nur Kholifah ${ }^{4}$, \\ Mustofa Abi Hamid ${ }^{5}$, Ary Purmadi ${ }^{6}$, Yasdin 7 , Sony Sukmara ${ }^{8}$, Dwi Widjanarko9, \\ R. Ahmad Zaky El Islami ${ }^{10}$, Nurcholish Arifin Handoyono ${ }^{11}$, Rabiman ${ }^{12}$ \\ mnurtanto23@untirta.ac.id ${ }^{1}$, fawaid80@gmail.com² ${ }^{2}$ soffan@ untirta.ac.id ${ }^{3}$, nur.kholifah@uny.ac.id ${ }^{4}$, \\ abi.mustofa@untirta.ac.id ${ }^{5}$, arypurmadi@ikipmataram.ac.id ${ }^{6}$, yasdin@unm.ac.id ${ }^{7}$, \\ sony_sukmara@yahoo.com ${ }^{8}$, dwi2_oto@mail.unnes.ac.id ${ }^{9}$, zakyislami@untirta.ac.id $^{10}$, \\ arifin@ustjogja.ac.id ${ }^{11}$, rabimanust@yahoo.com ${ }^{12}$
}

Universitas Sultan Ageng Tirtayasa, Serang, Indonesia ${ }^{1,2,3,5,10}$, Universitas Negeri Yogyakarta, Yogyakarta, Indonesia ${ }^{4}$, Institut Keguruan dan Ilmu Pendidikan Mataram, Mataram, Indonesia ${ }^{6}$, Universitas Negeri Makassar, Malang, Indonesia ${ }^{7}$, Universitas Negeri Semarang, Semarang, Indonesia $^{9}$, Universitas Sarjanawiyata Tamansiswa, Yogyakarta, Indonesia ${ }^{11,12}$

\begin{abstract}
One of electrical system character is that it is visually unobservable, but the change it brings can be detected. When analyzing the change in each component is presented as the difference of final result from their specifications. Thus the difficulties of understanding Ignition System with Contact Breaker (ISCB) working concept and failure analysis can be solved with Information Media Literacy (IML) using Problem-based Learning (PBL) approach. This research was conducted on 76 K-11 ( $\pm 19-21$ years old) as experiment group. The results indicated that students' conceptual comprehension posttest score statistically shows the significance of ISCB. The implication of Information Media Literacy, designed to solve problems in the contact breaker ignition system, is that it can effectively help students by facilitating conceptual ability.
\end{abstract}

Keywords: Information Media Literacy, Problem Based Learning, Ignition System Contact Breaker

\section{Introduction}

Ignition is part of the automotive electrical system; its role is to supply sparks in the combustion process Inseparable combustion concepts are (1) strong sparks, (2) high compression pressure, and (3) fuel mixture approaching stoichiometry [1], [2]. Therefore, the ignition system must be able to function in all machine conditions [3]. If the components are experiencing problems, it will have a detrimental effect on the spark quality, or even leading to misfire. As a result, the machine does not work optimally, or system malfunction may happen. Thus, studying the failure to each component with the analysis of the occurring phenomenon will facilitate students in the future to master the skills of diagnosis and repairers to the ignition system. 
The current phenomenon in the real world is components break down, solving this is a competence that must be mastered by automotive vocation students. Input from practitioners and experts regarding the failure in the ignition system should be conceptualized in the teaching plan, and then electrical media is made in such a way to simulate the real conditions. Students in groups should learn to solve the encountered problems by analyzing and evaluating the problem identification process [4].

System-supporting component failures cause ignition system problems. Sometimes the issues are in the preliminary phase, and sometimes they are not realized by the user. Other conditions, components of aging that has exceeded the age limit or other factors caused by nature. It allows the disruption of the ignition system and creates optimum components performance [5]. Students are expected to be able to sense the effects of component failures or physical changes that deviate from the standard conditions. Thus the normal and abnormal conditions become the benchmark to identify the problem. Next step is to test the components and build a hypothesis. This process is part of the PBL steps on the problem identification concept.

The process of problem identification requires knowledge competence, regarding electrical systems. In detail, it consists of knowledge about the components, the components functions, the component performance impact, and even the standard component measurement. These competencies are obtained through many possible methods. In the PBL class, students are conditioned to empower the Information Media Literacy they have. This method is considered more practical and useful; all students have the media in their online smartphone. The roles of media literacy in a broad sense are for the ability to understand, analyze, and construct [6], [7] and it is accessible. The conducted process is building a habit of reading and writing down obtained information. The use of IML in Problem-Based Learning concept develop insights and cultivating positive literacy. This method can also be used in other competence with IML approach.

Based on the description elaborated above, it can then be formulated into research questions as follows: (1) what are the characteristics of IML that can be developed for the ISCB concept of the automotive field that is PBL oriented? (2) After implementing IML, has the ISCB learning developed effectively to build the PBL concept?

\subsection{Ignition System Contact Breaker (ISCB) Electrical Part}

Conventional ignition has undergone technological developments. In principle, however, it still has similarities. In vocational education, competence in the traditional system is basic competence that must be studied and mastered as a requirement for the next advanced proficiency.

Some formal and non-formal vocational educators present lessons in different ways. However, the concept of performance that becomes the students' understanding is not changed. The presentation is in the form of demonstration media [8] by separating the ignition system from the more complex system. The other way to build understanding is teaching with visual media that is available in various online media. The same intended objective is the mastery of ignition system. However, the drawbacks of each learning media need to be addressed and complemented with understanding by IML.

Components in complex ignition system consist of: contactor key, fuse, ignition coil (primary and secondary) with internal or external resistors, high voltage cable, distributor (rotor, contact breaker), capacitor, and spark [9]. The process of sparkle in a very complicated way 
among ignition components. The heat transfer process that occurs between elements cannot be observed visually. The necessary explanation cannot show the loss factor. Required initial data and measurement data as well as visual observations to build robust analysis. Those knowledge and skills are expected to be mastered by students. Reconstructions made from various conditions are required so students can earn a preliminary investigation. With the help of IML students may identify problems that occur. The ignition system is illustrated as follows:

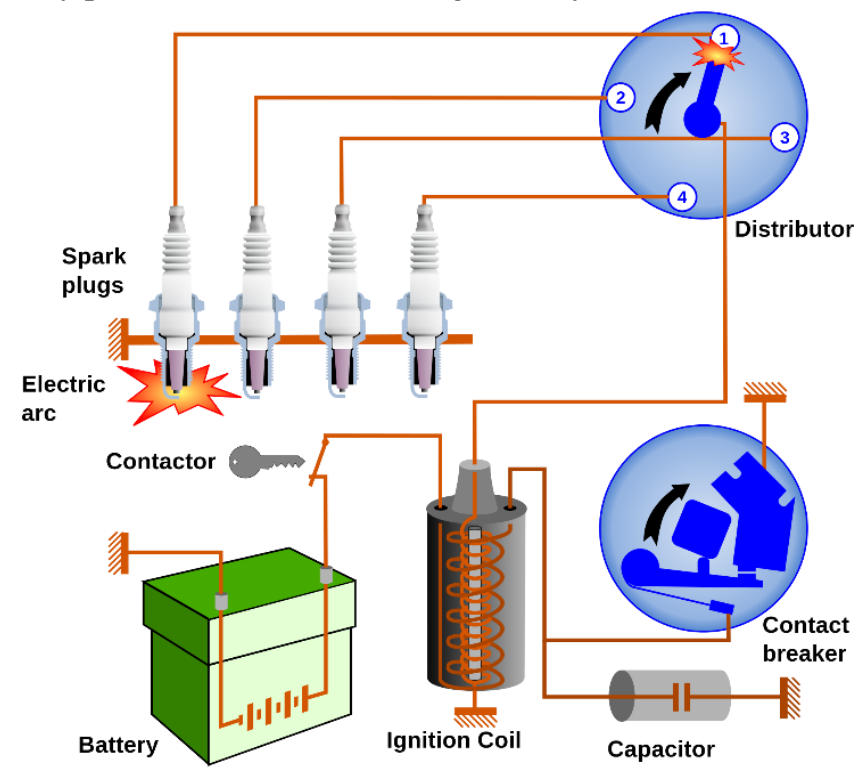

Fig. 1. The circuit Ignition System [9]

Ideal characteristics of the ISCB components are: ignition coil with no current leakage, no current or voltage loss, no limit for ignition timing angle, the resistor is maintained at interruption electromagnetic wave conditions. Often, because of the engine condition, the combustion process leaves residue combustion chamber due to slow propagation of fire [10]. Temperature and pressure affect the combustion system also, especially the heat transfer process [11]. The changes that occurred were noted and considered in failure analysis. Ignition stability [12], is the key to learning system objectives.

\subsection{ISCB Concept Comprehension with IML Support}

The globalization era gave birth to the role of media as literacy in the learning concept and industrial technology. Similarly, the characteristics of 21 st-century education, education 3.0, industry 4.0 and sustainable development goals (SDGs) emphasize learning innovation utilizing media literacy as information. Media literacy is part of needs for teenagers, even up to the addiction level. Rather than spending useless time for it, it should be directed to the utilization which provides a new understanding, especially in the learning concept.

Information Media Literacy uses internet of things (IoT) that are: communication, data sensing, device connection, data analytics, data value, and human value [13]. Elements which should be considered for education development in Indonesia are (1) education globalization in the form of cyber tech, internet of things (IoT) [14], competition, cloud computing, new technology; and (2) institution and structure (creativity, innovation, multi-discipline, 
entrepreneur, etc. Those two elements are integrated with each other, mainly because the carrying capacity of internet users in Indonesia for 2018 is around 123 (million) included in 5 clusters of the world. Enhancement of IoT for learning innovation will need digitalization strategy; it can be found in Siap online, Qbaca, Journal, English Bean, UmeetMe, Indischool, Smart Campus Award and India learning.

Table 1. Dimension of Digital Media Literacy

\begin{tabular}{|c|c|c|}
\hline & Device Literacy & Content Literacy \\
\hline Access & $\begin{array}{l}\text { Device ownership, access to } \\
\text { service }\end{array}$ & $\begin{array}{l}\text { Ability to search, find and filter relevant } \\
\text { content }\end{array}$ \\
\hline Understand & $\begin{array}{l}\text { Understand the fundamental } \\
\text { nature of technology and know- } \\
\text { how to operate and at a functional } \\
\text { level }\end{array}$ & $\begin{array}{l}\text { Ability to understand and analyze the } \\
\text { content critically }\end{array}$ \\
\hline Create & $\begin{array}{l}\text { Ability to produce, reproduce and } \\
\text { create content using digital } \\
\text { technology }\end{array}$ & $\begin{array}{l}\text { Ability to form opinions, ideas and } \\
\text { convert into digital content. Knowledge } \\
\text { of the social impact, cyber etiquette, and } \\
\text { ethics. }\end{array}$ \\
\hline
\end{tabular}

Source: Park (2011) [15]

Literacy is defined as "the approved ways of generating, communicating, and negotiating through text" [15]. In the education context, media literacy plays a role in education as comprehension renewal innovation as stated by Erstad [16]. Then the information media processing is in the form of "reading," accessing information, and "writing," producing and expressing contents so that it will open up a new competent dimension [17]-[19]. Thus reading literacy, writing literacy, media literacy become new movements that are applied to every learning process using literacy media. The use of literacy media in e-learning can improve students' learning outcomes. [20].

\subsection{PBL Characteristics using IML}

PBL is part of a student-centered scientific method of solving open, ambiguous, complex, exciting and needs-based problems in the real world that is sustainable [9], [21]-[23]. One of the most innovative learning styles recommended in vocational education is the scientific approach by exploring the utilization of problem-solving [22]. PBL is an instructional methodology that teachers use for students in solving globalization issues by integrating suitable information. Information is obtained through an authorized and reliable online source. The success in information selection lies in a reliable source and students should also be able to select and manage data as information back up.

The initial stage of PBL activity is problems identification from situations that require a solution. Using online mode, students enter appropriate keywords and then filtrate or sort data. Actions taken by students at this stage are among others accessing, exploring, analyzing, sharing, formulating, [24] and taking decisions [25]. The purpose of this pattern is to define the problem, to be investigated, and the process of communication [26] from different information already obtained. So teachers examine data and applying the characteristics of information media literacy in the form of critical thinking ability, i.e.: (1) transformative; (2) troublesome; (3) integrative; (4) irreversible; and (5) bounded. It is to limit the information obtained. Moreover, also to use the time efficiently. 
Next step, to process the problems given, students, with PBL approach should: (1) identify and search essential background sources of statistical information and reports from the original articles; and (2) list of information needs to be based on the things that are still unknown [21].

\section{Method}

The research objective is to analyze the effects of Information Media Literacy (IML) in promoting the conceptual understanding of Ignition System Contact Breaker (ISCB) with Problem Based Learning (PBL) patterns during the comprehension construction process. This study used a quantitative approach with pretest and posttest designs used by Creswell [27]. Measurement of the conceptual understanding of the experimental class uses one group with the following design.

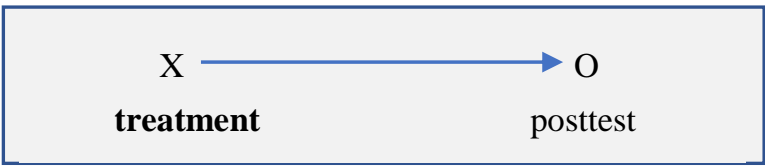

Information:

Fig. 1. Design One Group Posttest Only

O: Conceptual Understanding Media Literacy Tests using PBL Information

$\mathrm{X}$ : The scientific study learning in the platinum ignition system of the experimental group

A total of 76 respondents participated in this study. Respondents were drawn on the K-11 with $\pm 17-20$ years of age. The sample was selected randomly. Most of the students have been studying the concept of the contact breaker ignition system works. The achievement test, developed by the researcher in the form of conceptual understanding consisting of 2 open questions, is used as an instrument of data collection in the form of cause and troubleshooting. At the beginning of the meeting, a common problem in the industrial world was presented.

Table 2. Comprehension and IML Instrument

\begin{tabular}{|c|c|c|}
\hline Comprehension level & Variables & Sub Variables \\
\hline $\begin{array}{l}\text { understanding } \\
\text { conception }\end{array}$ & $\begin{array}{l}\text { Conceptual Information } \\
\text { Media Literacy using the } \\
\text { PBL approach in ISCB }\end{array}$ & $\begin{array}{l}\text { 1. Understanding Capabilities } \\
\text { 2. access Capabilities } \\
\text { 3. capability Evaluation }\end{array}$ \\
\hline
\end{tabular}

Problem 1.

During the trip with the car going less than $60 \mathrm{Km} / \mathrm{hour}$, engine was in normal condition. Last service was done at $880.000 \mathrm{Km}$ and at that time the vehicle age was $929.000 \mathrm{Km}$. Suddenly, after 4 hours driving with speed above $90 \mathrm{Km} /$ hour, the engine was off and, after testing, there was no park on the spark plug.

Explain why this problem may occur, do it with data testing!
a. Explain the possible cause!
b. How can we solve this problem?
c. What actually happened and proof the failure characteristics?

\section{Problem 2.}

Engine performance is not stable, at $1.000 \mathrm{Rpm}$ the spark is weak, what phenomenon is happening with this car?
a. Explain the possible cause!
b. How can we solve this problem?
c. What actually happened and proof the failure characteristics? 
For the PBL process, time to complete the learning is 180 minutes in small groups work and application of information media literacy. The instrument sheet and the required equipment have been prepared before. Initial comprehension has been measured to prepare for the system diagnosis stage. The student's responses in the PBL class are analyzed in two ways. First, identify the student's ability in the ISCB conception using PBL approach and their ability to use information media literacy. Capability analysis is an appropriate analytical method, which provides a general view of the academic level based on achievement test questions. On the other hand, information literacy capability is assessed to see the influence of IML in overcoming the problems in the PBL class. It is part of learning resources and learning innovation.

\section{Results and Discussion}

Stages for analyzing ISCB problems will include the stage of symptoms identification, the causes investigation, problem solution and the standard specifications of components. Problem analysis had been completed by students, and several failure causes had been identified, also the action to fix the problem. The failure causes identification process was substantially supported by information media that is read and written. Next, they build problem hypotheses and then determine the final action. After that, the action is analyzed based on the result. This process is called comprehension level reconstruction based on problem situation. The result of the analysis is presented in the table below.

Table 3. Symptom, Causes, Solution, and Component Specification

\begin{tabular}{|c|c|c|c|}
\hline Symptom & Cause Analysis & Solution & Spec \\
\hline \multirow{7}{*}{$\begin{array}{l}\text { Problem } 1 \\
\text { No spark in the spark- } \\
\text { plug }\end{array}$} & $\begin{array}{l}\text { Dead spark-plug or } \\
\text { excessive deposit }\end{array}$ & $\begin{array}{l}\text { Replace or clean or } \\
\text { adjust spark plug gap }\end{array}$ & $1.0 \pm 0.2 \mathrm{~mm}$ \\
\hline & $\begin{array}{l}\text { Excessive leakage in } \\
\text { high-voltage cable }\end{array}$ & replace & $\leq 25 \mathrm{~K} \Omega$ \\
\hline & $\begin{array}{l}\text { Dirty contact or out of } \\
\text { spec gap }\end{array}$ & Clean or re-adjust & angle $(<) 45^{\circ}$ \\
\hline & $\begin{array}{l}\text { Contact is closing or } \\
\text { opening all the time }\end{array}$ & $\begin{array}{l}\text { Adjust contact and return } \\
\text { spring }\end{array}$ & - \\
\hline & Dead coil & Replace coil an measure & $\begin{array}{l}\text { Primary: } \\
\text { Secondary: }\end{array}$ \\
\hline & $\begin{array}{l}\text { Faulty condenser cable } \\
\text { connector }\end{array}$ & Check connection & - \\
\hline & Dead condenser & $\begin{array}{l}\text { Replace condenser and } \\
\text { measure }\end{array}$ & $0,4 \mu \mathrm{f}$ \\
\hline \multirow[t]{6}{*}{$\begin{array}{l}\text { Problem } 2 \\
\text { Small spark }\end{array}$} & $\begin{array}{l}\text { Excessive deposit in } \\
\text { spark-plug }\end{array}$ & $\begin{array}{l}\text { Clean or replace the } \\
\text { Sparkplug }\end{array}$ & - \\
\hline & $\begin{array}{l}\text { Excessive leakage in } \\
\text { high-voltage cable }\end{array}$ & Replace & $\leq 25 \mathrm{~K} \Omega$ \\
\hline & Dirty distributor cap & Clean terminal & - \\
\hline & $\begin{array}{l}\text { Missing carbon on the } \\
\text { distributor cap }\end{array}$ & Replace distributor cap & - \\
\hline & Out of spec contact gap & Adjust & angle $(<) 45^{\circ}$ \\
\hline & $\begin{array}{l}\text { Misadjusted ignition } \\
\text { timing }\end{array}$ & Adjust ignition timing & $8^{0}$ \\
\hline
\end{tabular}


The findings from conceptual skills test are presented based on the level of IML understanding: understanding, ability to access, and evaluation skills. Findings from achievement tests are presented in the table below, and then the results are analyzed.

Table 4. Student's Conceptual comprehension level

\begin{tabular}{llccccccc}
\hline \multirow{2}{*}{ Comprehension level } & \multicolumn{1}{c}{ Criteria } & \multicolumn{5}{c}{ ISBC Concept } & Average \\
\cline { 2 - 6 } & Understand & Access & Evaluate & Avectly \\
\hline $\begin{array}{l}\text { Complete } \\
\text { comprehension (4) }\end{array}$ & $\begin{array}{l}\text { Correctly } \\
\text { answering all } \\
\text { questions }\end{array}$ & 35 & $46 \%$ & 39 & $51 \%$ & 37 & $49 \%$ & 37 \\
$\begin{array}{l}\text { Majority } \\
\text { comprehension (3) }\end{array}$ & $\begin{array}{l}\text { Minstake in } \\
\text { answers }\end{array}$ & 20 & $26 \%$ & 19 & $26 \%$ & 21 & $28 \%$ & 20 \\
$\begin{array}{l}\text { Faulty comprehension } \\
(2)\end{array}$ & $\begin{array}{l}\text { Vague or wrong } \\
\text { answers }\end{array}$ & 9 & $12 \%$ & 7 & $9 \%$ & 8 & $11 \%$ & 8 \\
No comprehension (1) & $\begin{array}{l}\text { Irrelevant answers } \\
\text { Not answering (0) }\end{array}$ & 9 & $12 \%$ & 7 & $9 \%$ & 7 & $9 \%$ & 7,3 \\
\hline
\end{tabular}

Based on the above table, the information obtained in the average level of each consecutive understanding of the concept of ISCB, there is the development of learning constructs using IML. The average score is at a medium level.

Results from the student's comprehension level test were analyzed for each item about ISCB-based problems, and then presented in the following table:

Table 5. Students Comprehension Level

\begin{tabular}{lllc}
\hline \multicolumn{1}{c}{$\begin{array}{c}\text { Comprehension } \\
\text { Characteristic Level }\end{array}$} & \multicolumn{1}{c}{ Answers characteristics } & \multicolumn{1}{c}{$\begin{array}{c}\text { ISCB Problem } \\
\text { Comprehension }\end{array}$} \\
\cline { 2 - 3 } High characteristics & $\begin{array}{l}\text { All questions A, B, and C are answered } \\
\text { correctly }\end{array}$ & $35(46)$ & $32(42)$ \\
Medium characteristics & One question is not answered or wrong & $15(20)$ & $18(24)$ \\
Low characteristics & Only one question is answered correctly & $18(24)$ & $16(21)$ \\
No characteristics & No answer at all & $8(11)$ & $10(13)$ \\
\hline$\sum$ :
\end{tabular}

$\sum$ : a total of students answering problems about ISCB based on the comprehension level

$\%$ : students percentage in ISBC problem comprehension

1: problem one from ISBC question

2: problem two from ISBC question

For effectiveness of Information Media Literacy used in PBL classes in the reconstruction of the conventional ignition system concept, the quantity is determined by the percentage of students at the median level, i.e., complete comprehension. The effectiveness of IML use on the working concept of ISCB helps students in PBL condition. 
Table 6. Effectiveness Percentage in the understanding working the concept of ISCB

\begin{tabular}{ccl} 
Conception level & Quantity $(\boldsymbol{\%})$ & Category \\
\hline Understanding & 46 & Medium \\
concept & & \\
Accessing concept & 51 & Medium \\
Evaluating concept & 49 & Medium \\
\hline Average & $\mathbf{4 9}$ & Medium \\
\hline
\end{tabular}

The table above shows that the MLD is on the medium average of $49 \%$, and needs to be increased for other competencies.

\section{Conclusion}

This study demonstrates the effectiveness of Information Media Literacy (IML) to improve conceptual comprehension about ignition system Contact Breaker (ISCB), to help students succeed and scientifically build an understanding about the concept of ISCB. The results demonstrated that the incorporation of learning with IML has the potential to develop students conceptual comprehension in the process of problem identification using the PBL method. Based on the results and discussion, it can be concluded that the results presented shows that students in the identifying problems at ISCB passed with higher significance. This finding strongly supports that the application of PBL in IML can be used as an alternative instructional tool, to help students develop conceptual comprehension about ignition system Contact Breaker (ISCB).

\section{References}

[1] Marsico, K., The Triangle Shirtwaist Factory Fire: Its Legacy of Labor Rights. Marshall Cavendish. (2009)

[2] Stein, L., The Triangle Fire. Cornell University Press. (2010)

[3] Abdel-Rehim, A., "Impact of spark plug number of ground electrodes on engine stability," Ain Shams Eng. J., vol. 4, pp. 307-316. (2013)

[4] Phumeechanya, N. and Wannapiroon, P., "Design of Problem-based with Scaffolding Learning Activities in Ubiquitous Learning Environment to Develop Problem-solving Skills," Procedia - Soc. Behav. Sci., vol. 116, pp. 4803-4808. (2014)

[5] Reif, K., "Fundamentals of automotive and engine technology: standard drives, hybrid drives, brakes, safety systems". Springer. (2014)

[6] Arke, E. T. and Primack, B. A., "Quantifying media literacy: development, reliability, and validity of a new measure," Educ. Media Int., vol. 46, no. 1, pp. 53-65. (2009)

[7] Fortuna, C. "Media literacy in sports" . http://digitalcommons.uri.edu/jmle/vol6/iss3/8/.

[8] Olayiwola, R. O. "Modeling and simulation of combustion fronts in porous media," $J$. Niger. Math. Soc., vol. 34, no. 1, pp. 1-10. (2015)

[9] Leibiger, C. A. "Google reigns triumphant? Stemming the tide of googlitis via collaborative, situated information literacy instruction," Behav. Soc. Sci. Libr., vol. 30, no. 4, pp. 187-222. (2011) 
[10] Tutak, W. and Jamrozik, A. "Characteristics of the flow field in the combustion chamber of the internal combustion test engine," Chem. Process Eng., vol. 32, no. 3, pp. 203-214. (2011)

[11] Lapuerta, M., Sanz-Argent, J., and Raine, R. R., "Ignition characteristics of diesel fuel in a constant volume bomb under diesel-like conditions. Effect of the Operation Parameters," https://pubs.acs.org/doi/abs/10.1021/ef500535j.

[12] Park, C., Oh, S., Kim, T., Oh, H., dan Bae, C., "Combustion characteristics of stratified mixture in lean-burn LPG direct-injection engine with spray-guided combustion system," presented in ASME 2014 Internal Combustion Engine Division Fall Technical Conference, 2014, pp. V001T02A005-V001T02A005.

[13] i-SCOOP, "The internet of things (IoT) - essential IoT business guide,". https://www.iscoop.eu/internet-of-things-guide/.

[14] Jamil, M. and Said, M., "The utilization of internet of things (IoT) for multi-sensor data acquisition using thing speak," VOLT J. Ilm. Pendidik. Tek. Elektro, vol. 3, no. 1. (2018)

[15] Park, S. "Dimensions of digital media literacy and the relationship with social exclusion," Media Int. Aust., vol. 142, no. 1, pp. 87-100. (2012)

[16] Ola, E. "Educating the Digital Generation - Exploring Media Literacy for the 21st Century - Nr Jubileumsnummer - 2015 - Nordic Journal of Digital Literacy - Idunn - tidsskrifter på nett." https://www.idunn.no/dk/2015/Jubileumsnummer/educating_the_digital_generation__exploring_media_literacy.

[17] Baron, D. E. "A better pencil: Readers, writers, and the digital revolution". Oxford University Press. (2009)

[18] Pahl, K. and Rowsell, J., "Literacy and Education: Understanding the New Literacy Studies in the Classroom". Paul Chapman Publishing, A SAGE Publications Company, Thousand Oaks. (2005)

[19] Melki, J. "Guiding Digital and Media Literacy Development in Arab Curricula Through Understanding Media Uses of Arab Youth,” J. Media Lit. Educ., vol. 6, no. 3, pp. 14-28. (2015)

[20] Ardiansyah, R. and Diella, D., "The effect of web-enhanced course (WEC) and web-centric course (WCC) towards student learning results on reproduction system concept," J. Penelit. Dan Pembelajaran IPA, vol. 3, no. 2, pp. 143-150. (2017)

[21] Macklin, A. S. "Integrating information literacy using problem-based learning," Ref. Serv. Rev., vol. 29, no. 4, pp. 306-314. (2001)

[22] Enger, K. B. et'al., "Problem-based learning: evolving strategies and conversations for library instruction," Ref. Serv. Rev., vol. 30, no. 4, pp. 355-358. (2002)

[23] Kenney, B., "Revitalizing the one-shot instruction session using problem-based learning," Libr. Publ. (2008).

[24] Suwana, F. and Lily, "Empowering Indonesian women through building digital media literacy," Kasetsart J. Soc. Sci., vol. 38, no. 3, pp. 212-217. (2017)

[25] Docherty, C., Hoy, D., Topp, H., and Trinder, K., "eLearning techniques supporting problem-based learning in clinical simulation," Int. J. Med. Inf., vol. 74, no. 7, pp. 527533 (2005)

[26] Vélez, A. P. and Zuazua, I. I., "Digital literacy and cyberconvivencia in primary education,” Procedia - Soc. Behav. Sci., vol. 237, pp. 110-117. (2017)

[27] Creswell, J. W., Research Design: qualitative, quantitative, and mixed methods approaches. SAGE Publications. (2009) 